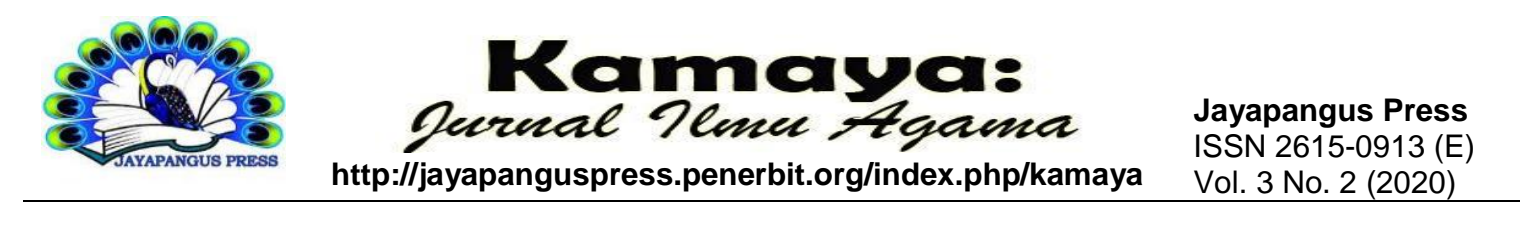

\title{
Haji Dalam Budaya Masyarakat Bugis Barru: Suatu Pergeseran Makna
}

\author{
Oleh: \\ Nasruddin \\ IAIN Parepare \\ zhafranaffank@gmail.com
}

\begin{tabular}{ll}
\hline Keywords: & Abstract \\
\cline { 1 - 2 } $\begin{array}{l}\text { Pilgrimage; } \\
\text { Meaning; } \\
\text { Buginese }\end{array}$ & $\begin{array}{l}\text { This research aims to reveal the change of the symbolic meaning } \\
\text { of pilgrimage. Type of this research uses a qualitative approach. } \\
\text { The research subjects were people who have carry out the } \\
\text { pilgrimage. Data were collected through observation, interview }\end{array}$ \\
& $\begin{array}{l}\text { and documentation technique. The data were analyzed through } \\
\text { qualitative descriptive using phenomenology approach. The } \\
\text { result of this research revealed that the forms of the change of } \\
\text { pilgrimage symbolic meaning are shown through the ceremony } \\
\text { of mappatoppo and construction clothes of the pilgrim. Factors } \\
\text { encouraging those changes were social status and prestige asa } \\
\text { well as expected appreciation. }\end{array}$ \\
\end{tabular}

Kata kunci:

Haji; Pergesaran

Abstrak
Penelitian ini bertujuan mengetahui pergesaran makna simbolik
haji pada masyarakat bugis Barru. Jenis penelitian ini
menggunakan pendekatan kualitatif. Subjek penelitiannya
adalah orang-orang yang berstatus haji. Teknik pengumpulan
data yang digunakan adalah teknik wawancara, observasi, dan
dokumentasi. Data tersebut dianalisis deskriptif kualitatif
menggunakan pendekatan fenomenologi. Hasil penelitian ini
mengungkapkan bahwa bentuk-bentuk pergeseran makna
simbolik haji dapat dilihat dari upacara mappatoppo dan
konstruksi pakaian. Adapun faktor yang mendorong terjadinya
pergeseran makna simbolik haji yaitu status sosial, gengsi sosial
dan ingin dihargai.

\section{Pendahuluan}

Sejak raja-raja Bugis dan Makassar pada abad ke 17 mulai masuk Islam, mereka menerima Islam sebagai resmi kerajaaan dan mengajak serta memaksa kerajaan-kerajaan lain, khususnya kerajaan Bugis Makassar untuk memeluk Islam, maka sejak itu pula masyarakat Bugis baik yang ada di pesisir pantai maupun yang ada di pedalaman juga 
menerima Islam sebagai agama mereka bahkan mereka dikenal sebagai penganut Islam yang taat dan ketat (Mukhlis, 1999). Hal ini disebabkan pengaruh kekuasaan di kerajaan, sehingga masyarakat Bugis memeluk agama Islam secara merata, dan juga karenasara', yakni pranata Islam dimasukkan dalam sistem pranata sosial budaya orang Bugis yang disebut pang'ade'reng, sehingga "agama Islam bagian dari landasan kultural mereka serta turut membentuk identitas mereka sebagai orang Bugis” (Mattulada, 1995).

Pranata Islam diintegrasikan ke dalam pang'ade 'reng sehingga alam pikiran dan kepercayaan masyarakat Bugis pun sebelum Islam tetap berkembang bersama dengan ajaran Islam. Meskipun “di dalam pang'ade'reng itu banyak terdapat unsur-unsur yang bertentangan dengan hukum Islam dan bahkan dapat dimasukkan kedalam kategori syirik akan tetapi pengintegrasian itu berjalan dengan bertahap dan lambat laun sara' itu memberi warna Islam kepada pang'ade' reng itu”' (Sajogyo, 2005).

Mulkhan (1998) menyatakan bahwa nilai-nilai yang berlaku dalam masyarakat Bugis, sebagian bersumber dari ajaran Islam dan sebagian yang lain bersumber dari tradisi yang ada dan berkembang dalam masyarakat secara luas. Pemahaman terhadap nilai-nilai ajaran Islam, berkaitan dengan realitas dan masalah-masalah sosial, budaya dan politik. Namun dalam praktek kehidupan sosial, seringkali terjadi jarak yang lebar antara norma, nilai, kaidah ajaran dengan realitas sosial.

Seiring dengan perkembangan Islam dan meningkatnya penganut agama Islam di masyarakat Bugis, maka praktek-praktek syariat Islam pun menjadi hal penting dalam sistem sosial, budaya dan religi mereka, seperti shalat, puasa, zakat dan haji. Sebagai rukun Islam yang kelima, ibadah memiliki peranan yang cukup signifikan dalam menentukan orientasi keislaman orang Bugis sebab pandangan orang Bugis seperti juga orang-orang Islam di Indonesia pada umumnya, keislaman seseorang baru dapat dikatakan sempurna jika telah melaksanakan rukun yang kelima itu karena ibadah haji adalah ibadah yang diwajibkan Allah Swt bagi orang-orang yang dianggap mampu.

Oleh karena itu, meski harus menempuh perjalanan begitu jauh, sulit dan berbahaya, orang Bugis tetap beramai-ramai menunaikan ibadah haji. Bagi mereka justru dengan rintangan perjalanan yang begitu sulit haji dianggap memiliki banyak pahala dan juga memiliki kaitan kausatif dengan dinamika kehidupan sosial, ekonomi, dan budaya masyarakat. Dalam kondisi yang demikian, posisi ibadah haji pada masyarakat Bugis menjadikan ibadah haji ini sebagai ibadah yang senantiasa diorientasikan dan dicitacitakan oleh setiap orang Bugis. Dalam perkembangan selanjutnya, ibadah haji ini 
ternyata tidak semata-mata bercorak keagamaan saja, karena corak sosial, ekonomi dan budaya juga sangat pekat dan include di dalamnya. Hal ini disebabkan karena dalam ibadah haji ini, hanya orang-orang yang mampu diwajibkan untuk menunaikannya. Mampu yang dimaksud disini adalah mereka yang mampu baik secara finansial maupun secara spiritual, serta lahir batin. Kategori mampu ini kemudian berkembang ke ranah sosial yang begitu luas dalam masyarakat Bugis, khususnya Kelurahan Takkalasi. Akibatnya, mampu hanya diartikan sebagai orang yang memiliki pendanaan dan kekayaan sehingga mampu membiayai perjalanannya ke Tanah Suci yang semakin lama semakin mahal, tanpa melihat kemampuan psikologis dan kematangan spiritual dalam berhaji. Sehingga tidak heran jika ada beberapa orang Bugis yang meski telah menunaikan ibadah haji, tetapi kelakuannya masih tetap tidak mencerminkan sikap seorang muslim. Sepertinya predikat haji mabrur tidak menjadi perhatian mereka sebab status sosial jauh lebih penting dalam proses bermasyarakat.

Meski tidak semua orang yang berhaji berperilaku demikian, tetapi pola berhaji seperti ini tampaknya telah menjadi selera umum di dalam masyarakat Bugis di Kelurahan Takkalasi, sebab walaupun ada beberapa kelompok masyarakat melihat gejala ini secara kritis, tetapi mereka tidak memiliki kuasa untuk menentang praktek haji seperti ini. Hal ini barangkali karena fenomena tersebut dibungkus dengan kemasan ibadah atau agama, sehingga ia menjadi masalah yang seolah-olah tidak bisa dianalisis dan orang menjadi riskan mengkritiknya. Sulit dibantah siapapun yang berakal sehat bahwa segala sesuatu hal yang bisa memberi keragaman kenikmatan di sekitar kehidupan berbentuk benda-benda yang dapat dilihat (invisible) dan dirasakan (sense). Semua benda itu berkarakter biologis, kebendaan, perangkat keras, dan perangkat lunak. Bahkan dalam kondisi tertentu, benda-benda tersebut dapat secara sangat mudah dijumpai. Kondisi demikian melahirkan pandangan materialism, bahwa ukuran kenikmatan dan keberhasilan hidup di dunia adalah ketersediaan kebutuhan benda materi. Tak pelak lagi, ketika kesenangan kehidupan dunia merajai hati seseorang, maka kedudukan dan peranan Allah kian mengecil dan bahkan hilang sama sekali dari hati manusia. Ketikan itu, god spots seseorang semakin tertutupi kabut materi bendawi (Sensa \& Artyasa, 2004). Agar kehidupan manusia terasa sangat nyaman dan indah dalam sinergi kebutuhan jasmani dan rohani meskipun dalam kemasan simbolis ritual ibadah haji ditetapkan oleh-Nya sebagai media pembentukan karakter, ritual-ibadah haji adalah simbol-simbol ritualsakral yang nilai hakikatnya harus ditangkap oleh pelakunya. 
Fenomena empirik yang menunjukkan terjadinya pergeseran makna simbolik haji pada Masyarakat Bugis di Kelurahan Takkalasi yaitu Nampak pada acara yang berhubungan dengan sosial keagamaan, seperti acara pernikahan, mereka memberikan tanda kepada diri mereka dengan mengidentifikasi diri untuk membedakan mereka dengan orang yang belum berhaji, hal tersebut merupakan cara mereka dalam mengalihkan perhatian ke masyarakat umum demi mendapatkan pengakuan. Seseorang yang sudah berhaji harus dipanggil dengan sebutan haji atau hajjah dan apabila mereka tidak dipanggil demikian, maka mereka akan merasa tidak dihargai. Bahkan diantara mereka ada yang menjaga jarak dengan orang yang tidak bergelar haji.

Dari fenomena yang menunjukkan terjadinya pergeseran makna simbolik haji pada masyarakat Bugis di Kelurahan Takkalasi, maka penulis perlu mengungkapkan hasil penelitian yang pernah dilakukan oleh beberapa peneliti yang berhubungan dengan masalah ini sebagai perbandingan penelitian penulis, diantaranya adalah Tim Peniliti BPLK Ujung Pandang mengadakan penelitian pada Tahun 1997/1998 yang di Ketuai oleh H.P Badrun, dengan judul penelitian "Dinamika Haji di Sulawesi Selatan”. Mereka memberikan kesimpulan sebagai berikut: (1) Haji sebagai salah satu bentuk ibadah memiliki pensyaratannya yang jauh lebih berat dibandingkan dengan bentuk-bentuk ibadah lainnya dalam agama Islam. (2) Meningkatnya jumlah calon jamaah haji asal daerah Sulawesi Selatan setiap tahun, terutama sejak pelita II, disebabkan karena meningkatnya pendapatan masyarakat, disamping faktor-faktor pendukung lainnya serta meningkatnya kesadaran beragama masyarakat serta kemudahan prosedur pengurusan pendaftaran. (3) Ingin menunjukkan tanda kesempurnaan Islamnya; ingin memperoleh imbalan pahala berlipat ganda yang dijanjikan Allah dan Rasul-Nya; ingin memperoleh pengakuan sosial dalam rangka kemudahan melakukan peran-peran sosial. (4) Pada dasarnya tidak terdapat perbedaan berarti tentang pandangan masyarakat dengan latar belakang komunitas yang berbeda dengan ibadah haji dan orang haji.(5) Seirama dengan adanya perbedaan kecenderungan motivasi haji, antara golongan santri dan non santri terdapat perbedaan antara kedua golongan adalah proses persiapan keberangkatan dan dalam pelaksanaan ibadah haji itu sendiri. (6) Status haji pada dasarnya tidak merubah posisi seseorang dalam struktur sosial yang baku. (7) Persepsi orang haji terhadap penyelenggaraan dan pelayanan haji (oleh pihak pemerintah pada dasarnya terkesan positif namun demi penyempurnaan, mereka menyarankan hal-hal yang menurut pengalaman mereka masih terdapat kekurangan-kekurangan. 
Dari penjelasan hasil penelitian di atas, maka penulis perlu mengungkapkan usulan penelitian penulis yang dianggap berbeda dengan penjelasan kesimpulan hasil penelitian di atas.Yang menjadi judul penelitian penulis yaitu "Pergeseran Makna Simbolik Haji pada Masyarakat Bugis di Kelurahan Takkalasi Kecamatan Balusu Kabupaten Barru". Oleh karena itu, munculnya fenomena pergeseran makna simbolik haji sesungguhnya merupakan suatu gejala budaya masyarakat yang memanfaatkan agama, khususnya ibadah haji untuk mendapatkan status sosial. Dalam konteks ini, ibadah haji tidak lagi dimaknai layaknya makna ibadah haji yang sesungguhnya.Karena haji telah menjadi "komoditas tanda" yang senantiasa diperebutkan untuk mendapatkan legitimasi dan manfaat-manfaat simbolik.

Seseorang yang pergi melaksanakan ibadah haji adalah mereka yang sudah siap meninggalkan sebagian besar atribut dunia dan apa saja yang ada dilingkungannya, termasuk segala hal yang menjadi miliknya. Istri, suami, anak-anak, rumah-rumah, dan perdagangan yang sangat dicintainya. Demikian pula orang tua dan anak-anaknya, serta harta benda yang telah diusahakannya selama sekian tahun. Jadi, segala atribut dunia yang memberinya sejumlah kenikmatan tanpa batas seperti kegiatan bisnis, peluang untuk memeroleh status sosial dan handai tolan yang selalu membutuhkannya setiap saat untuk sementara harus ditepiskannya jauh-jauh. Cara ini merupakan langkah efektif bagi kecintaan yang berlebihan kepada selain Allah, artinya Allah mengajarkan kepada pelaku haji agar setelah melaksanakan ibadah haji tanpa menjadikan tolak ukur kecintaan kepada pangkat, kedudukan, kekayaan, kebangsawanan dan lain sebagainya yang bersifat duniawi.

Penelitian ini bertujuan untuk mengungkapkan bentuk-bentuk pergeseran makna simbolik haji pada masyarakat Bugis Barru dan faktor yang mendorong terjadinya pergeseran makna simbolik haji pada Masyarakat Bugis di Kelurahan Takkalasi Kecamatan Balusu Kabupaten Barru. Hasil penelitian ini menyediakan kontribusi. Pertama, dalam rangka meningkatkan sumber daya manusia yang berkreatif dan berkreasi maka penelitian ini dapat dijadikan sebagai bahan referensi bagi ilmuan dalam pengembangan ilmu pengetahuan melalui penelitian terhadap persoalan-persoalan sosial keagamaan. Kedua, hasil penelitian ini berkontribusi praktis dalam mendorong para haji untuk bersikap dan berperilaku sesuai dengan nilai-nilai spiritual dan sosial keagamaan dan sebagai bahan informasi bagi masyarakat agar dalam melaksanakan ibadah haji harus disertai dengan keikhlasan semata-mata karena Allah SWT, bukan karena untuk mendapatkan status sosial. 


\section{Metode}

Penelitian ini merupakan jenis penelitian deskriptif kualitatif dengan pendekatan fenomenologi. Mayer dan Greenwood (2009) menyatakan bahwa penelitian deskriptif kualitatif adalah penelitian mengacu pada identifikasi sifat-sifat yang membedakan atau karakteristik sekelompok manusia, benda, atau peristiwa. Pendekatan fenomenologis yaitu pendekatan yang menggunakan perbandingan sebagai sarana interpretasi yang utama untuk memahami arti dari ekspresi-ekspresi keagamaan (Kahmad, 2006). Moleong (2006) menyatakan bahwa fenomenologi diartikan sebagai pengalaman subjektif atau pengalaman fenomenologikal dan suatu studi tentang kesadaran dari perspektif pokok dari seseorang. Teori interaksionisme simbolik mengacu pada tindakan manusia terhadap sesuatu atas dasar makna-makna yang dimiliki benda-benda itu (Badrun, 1997).

Penelitian ini sifatnya studi kasus yang memfokuskan kepada terjadinya pergeseran makna simbolik haji pada masyarakat Bugis. Penelitian ini dilakukan di Kelurahan Takkalasi Kecamatan Balusu Kabupaten Barru sebagai lokasi penelitian dengan memilih 20 orang dari beberapa informan antara lain; informan ahli dalam hal ini adalah tokoh agama, tokoh pendidik, tokoh masyarakat, dan dari informan kunci atau subjek itu sendiri dan informan biasa atau orang yang belum berhaji sebagai perbandingan dan dapat memberikan informasi mengenai terjadinya pergeseran makna simbolik haji pada masyarakat Bugis di Kelurahan Takkalasi.

Teknik pengumpulan data yang digunakan dalam penelitian ini yaitu observasi partisipatif, teknik wawancara, dan dokumentasi. Teknik triangulasi dilakukan dengan maksud mengecek ulang derajat keterpercayaan data atau informasi yang telah diperoleh. Triangulasi yang dilakukan adalah triangulasi metode, menurut Patton (dalam Moleong, 2006), bahwa terdapat dua strategi dalam teknik ini yaitu (1) pengecekan derajat kepercayaan penemuan hasil penelitian beberapa teknik pengumpulan data; (2) pengecekan derajat kepercayaan beberapa sumber data dengan metode yang sama.

\section{Hasil dan Pembahasan}

\section{Islam dan Haji pada Masyarakat Bugis}

Dalam Lontarak Latoa dikatakan bahwa, "naia wari'e iana passekiwi assieajingenna tan massieajingnge"... "nakko de'ni wari'e tessituru'ni tau tabbe'e, yang berarti wari' itu memperkuat kekeluargaan negara yang sekeluarga ... apabila hilang wari' 
itu maka tak bersepakatlah rakyat. Dengan demikian dapat dikatakan bahwa "mempertahankan pelapisan sosial merupakan salah satu syarat untuk memperkuat negara atau kemakmuran dan kesejahteraan suatu masyarakat atau negara karena apabila pelapisan sosial tidak dipertahankan dan dipelihara, maka rakyat tidak akan bersepakat (Arfah \& Amir, 1993).

Agama merupakan unsur penting yang menentukan identitas suatu masyarakat. Oleh karena itu, diterimanya Islam sebagai agama orang Bugis merupakan suatu peristiwa yang sangat penting. Orang Bugis dianggap termasuk diantara orang Indonesia yang paling kuat dan teguh memeluk ajaran Islam. Memang hampir semua orang Bugis adalah penganut agama Islam. Para penganut agama Islam biasanya dipersatukan suatu ikatan persaudaraan sesama muslim (ukhuwah islamiyah) yang menjadikan muslim yang satu bersaudara dengan muslim lainnya. Di Sulawesi Selatan khususnya pada masyarakat Bugis, minat masyarakat (umat Islam) menunaikan ibadah haji semakin meningkat ditandai dengan semakin meningkatnya jumlah jamaah haji yang berangkat ke Mekah menunaikan ibadah haji setiap tahun. Fenomena ini diasumsikan mempunyai kausatif dengan dinamika kehidupan keagamaan, sosial, ekonomi dan budaya masyarakat.

Awal munculnya haji di Kelurahan Takkalasi tidak terlepas dari peran para ulama yang pernah belajar agama Islam di Mekah.Mereka mampu mempengaruhi masyarakat dengan melakukan pendekatan persuasif dengan para bangsawan karena pada saat itu masyarakat sangat tunduk dan patuh pada kaum bangsawan. Pada dekade ketiga abad XX, pengajaran agama, terutama ibadah dan belajar mengaji (membaca Al-Qur'an), masih diselenggarakan dengan cara tradisional, berupa pengajian dan pembacaan kitab oleh seorang ulama.

Perkembangan jumlah haji pada 10 tahun terakhir dapat dilihat dari beberapa faktor; pertama, makin banyaknya penduduk dan masyarakat muslim di Kelurahan Takkalasi serta meningkatnya pemahaman masyarakat tentang kedudukan ibadah haji sehingga mereka merasa berkewajiban untuk melaksanakannya jika telah mempunyai kemampuan untuk itu. Kedua, semakin meningkatnya jumlah pendapatan masyarakat serta pemerintah memberikan bantuan dari segi biaya berupa kredit Bank bagi masyarakat yang ingin melaksanakan ibadah haji. Ketiga, makin mudah dan teraturnya perjalanan haji.kemudahan itu ditandai dengan semakin lancarnya hubungan alat transportasi penerbangan ke Timur Tengah (Mekah), terutama dengan tersedianya alat transportasi khusus untuk pengangkutan haji baik pergi maupun pulang. Keempat, 
meningkatnya keinginan dari kaum perempuan dalam melaksanakan ibadah haji walaupun tidak didampingi oleh muhrimnya.

Dalam perkembangan jumlah jamaah haji pada 2004 - 2019 mengalami pasang surut, hal ini disebabkan karena adanya kebijakan pemerintah yang memberikan kuota haji atau pembatasan pemberangkatan jamaah haji untuk setiap kabupaten, kecamatan dan kelurahan setiap tahunnya. H. H.A (48 tahun), salah seorang pembimbing haji mengatakan bahwa tahun 2004 sebagai awal pemberlakuan kuota haji sehingga pemerintah Indonesia telah membatasi jumlah jamaah haji yang berangkat setiap tahunnya atas permintaan pemerintah Arab Saudi, sebab daya tampung jamaah dari Indonesia terkadang melebihi kapasitas jamaah yang ditentukan setiap tahunnya. Oleh karena itu, jumlah jamaah haji dibatasi pada setiap tahun. Perubahan cara berhaji akhirakhir ini dapat dianalisa dari pemahaman masyarakat yang lebih mendahulukan perempuan berhaji daripada laki-laki misalnya dalam suatu keluarga, kemanpuan berhaji secara finansial hanya untuk satu orang maka yang cenderung didahulukan adalah perempuan (isteri) sehingga akhir-akhir ini yang lebih banyak berhaji adalah perempuan.

\section{Bentuk-Bentuk Pergeseran Makna Simbolik Haji}

\section{a. Mappatoppo}

Ritual mapptoppo kegiatan ritual yang dilakukan oleh seseorang yang melaksanakan ibadah haji, setelah mereka melaksanakan wukuf di Padang Arafah dan melontar jumrah. Ritual mappatoppo atau menyematkan lipatan taliling (kerudung panjang yang digulung dan dililitkan di kepala perempuan yang berhaji) serta songkok haji bagi haji laki-laki sebagai bentuk peresmian penyempurnaan rukun Islam dan sebagai salah satu panutan dari Rasulullah SAW menurut pandangan orang-orang Bugis.

Ritual mappatoppo merupakan ritual yang memiliki makna mendalam, seperti doa yang dipanjatkan para haji pada saat melakukan ritual mappatoppo. Kemudian diucapkan doa "Allahumma hajjan mabruran wasa'yan masykura" "Ya Allah, jadikanlah hajiku sebagai haji mabrur dan masukkan aku dalam golongan orang-orang yang bersyukur".

Makna mabrur seperti yang dikatakan dalam doa tersebut, dari segi semantik kata mabrur berasal dari bahasa Arab yang artinya mendapatkan kebaikan atau menjadi baik. Kalau kita lihat akar katanya, kata mabrur berasal dari kata barra yaitu berbuat baik atau patuh. Dari kata barra ini kita bisa mendapatkan kata birrun, al-birru artinya 
kebaikan dan sering juga kita artikan sebagai ibadah haji yang diterima Allah SWT. Dengan kata lain, hajimabrur adalah haji yang mendapatkan kebaikan atau haji yang pelakunya menjadi baik.

Kebaikan yang dimaksud dalam doa mappatoppo mencakup dari semua kebaikan dari berbagai macam kebaikan yang diperintahkan Allah kepada para haji seperti berbuat baik kepada Allah melalui shalat, berbuat baik kepada sesama manusia dengan melalui sedekah atau tidak memandang rendah orang lain, berbuat baik kepada diri sendiri dengan membiasakan berpuasa, berbuat baik kepada alam dan sebagainya. Makna dalam upacara mappatoppo sebenarnya dapat kita ketahui pada saat Rasulullah menyampaikan pidatonya di Padang Arafah dengan mengatakan Al-hajju'Arafah artinya ibadah haji yang sesungguhnya adalah di Padang Arafah yakni meresapi nilai-nilai ketuhanan dan nilai-nilai kemanusiaan universal. Sebab, di Arafah juga di demonstrasikan berkumpulnya segala bangsa, dari warna kulitnya ada yang berwarna putih, kuning, sawo matang sampai berkulit hitam. Menurut al-Qur'an pada dasarnya memang semuanya sama. Barangsiapa memandang orang lain lebih rendah dari dirinya hanya karena warna kulitnya, tempat kelahirannya, bentuk tubuhnya dan sejenisnya maka itu diistilahkan rasisme dan rasisme itu dosa pertama yang dilakukan oleh makhluk yang bernama Iblis menolak sujud kepada Adam hanya karena Iblis diciptakan darid api, dan Adam diciptakan dari tanah. Kemudian Iblis itu merasa lebih unggul dari Adam.

Dari uraian di atas, dapat disimpulkan bahwa ibadah haji mengajarkan kepada pelakunya agar tidak menjadi angkuh, sombong dan senantiasa memahami dan mengaplikasikan nilai-nilai haji yang dituntun oleh ajaran agama Islam sebagaimana dicontohkan oleh Rasulullah Muhammad SAW.

Haji merupakan aspek formal puncak kesempurnaan Islam seseorang maka konsekuensi sosialnya seorang haji dipandang telah mencapai derajat Islam yang sempurna, meskipun pada tataran perilaku beragama tidak selamanya demikian, artinya tidak ada kohesi antara nilai haji sebagai doktrin dengan nilai haji sebagai aspek perilaku. Dengan demikian masyarakat akan menghargai para haji jika memenuhi kriteria-kriteria beragama yaitu mempunyai sikap istiqamah dan komitmen yang utuh dalam menjalankan kewajiban-kewajiban agama. Oleh karena itu, melaksanakan ibadah haji menurut ajaran Islam yang tertuang dalam upacara mappatoppo mengandung arti bahwa predikat sebagai haji mabrur tidak sekedar sebagai hadiah ketika melaksanakan ibadah haji melainkan merupakan suatu nilai yang menuntut adanya sikap dan perbuatan yang mendukung 
setelah menyandang gelar haji maka maka seseorang harus berupaya keras memelihara sikap dan tindakan yang kurang baik, baik yang biasa mereka lakukan sebelum berhaji maupun maupun setelah berhaji.

Dari hasil temuan melalui waawancara, tampak makna simbolik haji yang tertuang dalam upacara mappatoppo telah mengalami pergeseran.Hal ini dapat kita lihat kasus yang terjadi di masyarakat Bugis di Kelurahan Takkalasi. Para haji berjejer menunggu tamu undangan dalam suatu acara pernikahan, mereka mengidentifikasi diri diri dengan cara menjaga jarak dengan orang yang tidak berhaji dan menduduki tempat yang mereka anggap terhormat. Teori interaksionisme simbolik memandang bahwa memang pada dasarnya manusia dalam melakukan interaksi pasti memberikan simbol pada dirinya supaya merasa teridentifikasi dengan melalui simbol tersebut .Simbol yang biasa dipakai para haji dalam acara-acara tradisi orang Bugis seperti mispa, kebaya, cipocipo, dan songkok haji.

\section{b. Konstruksi Pakaian}

Konstruksi pakaian dapat dilihat dari Pakambang, Taliling, Mispa', dan Surubeng. Pertama adalah Pakambang. Pakambang (jubbah hitam) adalah salah satu simbol pakaian haji yang dikenakan kepada perempuan yang sudah berhaji pada masyarakat Bugis, pakaian tersebut dikenakan dipundak haji perempuan sebagai makna bahwa haji merupakan tanggung jawab dan amanah yang harus dijaga dengan baik. Keteguhan dan kebulatan tekad setelah mereka pakai pakaian tersebut biasanya para perempuan yang belum berhaji biasanya memperebutkan pakaian itu kemudian mereka memakainya dan mengatakan: "Upakai pakambangna hajjie, barekkuammengngi uruntu'i barakka'na waccinrola menre ritana marajae passukku'i asellengekku'. Saya pakai pakaian haji ini, mudah-mudahan saya dapatkan berkahnya orang yang melaksanakan ibadah haji untuk menyempurnakan Islam saya. Orang yang belum berhaji biasanya memakai pakaian pakambang dijadikan sebagai sennung-sennungeng (perantara) alat sebagai pappalomo dale (mempermudah rezeki), sambil berniat dengan hati yang tulus untuk melaksanakan ibadah haji.

Kedua adalah Taliling. Ada tradisi yang berlaku dalam masyarakat Bugis bahwa para haji perempuan dianjurkan memakai taliling (kain yang sejenis kerudung panjang yang dililitkan pada kepala perempuan), pada saat pertama kali mereka tiba di tempat tinggalnya, maka para haji dianjurkan memakai pakaian tersebut selama 40 hari berturutturut atas anjuran dari syekh pembimbing. Praktek tersebut dianggap sebagai cara mereka 
dalam menjaga kemabruran hajinya sambil melafadzkan doanya sebagai berikut "Allahu waliyul mukminin" (Ya Allah jadikan aku walinya orang-orang mukmin dan menjadi terhormat di tengah masyarakat) seperti yang tertuang dalam ritual mappatoppo. Namun sekarang taliling tersebut jarang digunakan dan biasanya diganti dengan cipo-cipo (penutup kepala) saja karena memakai cipo-cipo jauh lebih praktis daripada menggunakan taliling.

Ketiga adalah Mispa'. Salah satu konstruksi pakaian yang sering dipakai perempuan yang berstatus haji adalah mispa' (kerudung panjang dari kain yang tipis dan disulam dengan berbagai macam motif) pakaian tersebut disimbolkan dengan bentuk pengorbanan seseorang secara finansial dalam melaksanakan ibadah haji. Mispa' adalah pakaian yang dianggap memiliki banyak fungsi seperti digunakan sebagai aksesoris untuk menambah keanggunan dan dipercaya dapat menambah aura bagi pemakainya. Pakaian mispa' juga membantu cipo-cipo (penutup kepala) perempuan yang berstatus haji dalam mengidentifikasi diri dan memperjelas gelar haji yang disandangnya sehingga pakaian ini sering dipakai di tempat keramaian seperti acara pernikahan.Hal ini dilihat di acara-acara pernikahan pada masyarakat Bugis.

Keempat adalah Surubeng. Surubeng adalah salah satu pakaian laki-laki yang berstatus haji, pada awalnya surubeng digunakan bersama songkok haji terutama para haji pertama kali menginjakkan kakinya di tanah air. Pemakaian surubeng pada laki-laki seperti halnya pemakaian mispa pada perempuan dianggap sebagai tindak lanjut dari ritual mappatoppo yang sebelumnya dilakukan di tanah suci, dari dulu surubeng dianggap sangat erat kaitannya dengan simbol ketakwaan serta menjadi alat untuk mengkukuhkan haji seseorang, namun yang terjadi sekarang adalah para haji hampir tidak pernah lagi menggunakan surubeng baik pada acara-acara sosial kemasyarakatan ataupun acara keagamaan, yang tampak menggunakan surubeng hanyalah kyai atau tokoh agama. Di samping sebagai alasan kepraktisannya, surubeng tidak lagi dapat dipakai begitu saja oleh seorang haji karena ada diantara mereka menganggap bahwa tokoh agamalah yang berhak memakainya dan kurang cocok digunakan bagi mereka yang belum tinggi tingkat pemahaman agamanya apalagi banyak diantara para haji yang niat utamanya menunaikan ibadah haji bukan karena ingin menyempurnakan keislamannya melainkan ingin menaikkan strata sosialnya. 


\section{Faktor Pendorong Terjadinya Pergeseran Makna Simbolik Haji}

\section{a. Faktor Status Sosial}

Ibadah haji merupakan realisasi dari rukun yang kelima; hanya diwajibkan bagi orang-orang yang isthita'ah (mampu) yaitu mampu secara fisik (jasmani), rohani(spiritual) dan finansial (materi). Ketiga kemampuan ini merupakan syarat mutlak yang dijadikan sebagai ukuran religiusitas dalam melaksanakan ibadah haji. Pertama, adalah kemampuan fisik, istitha'ah dari sisi fisik disini yang dimaksud adalah mempunyai standar fisik yang cukup memadai karena ibadah haji merupakan perjalanan spiritual panjang yang memerlukan kekuatan fisik, tenaga ekstra serta kondisi yang senantiasa fit. Aspek yang kedua, adalah mampu secara finansial, tentunya kemampuan finansial terbatas pada negara-negara yang jaraknya jauh dari tanah suci seperti Indonesia. Ada fenomena sosial yang terjadi dalam masyarakat Bugis, biasanya masyarakat menganggap bahwa kemampuan yang dimaksud disini berpusat pada kemampuan finansial seseorang.Mereka menganggap bahwa orang yang telah berhaji berarti mereka memang sudah sangat mampu dari segi materi. Aspek yang ketiga, adalah mampu dalam segi ibadah, yaitu berkaitan dengan pemahaman ibadah pada diri seseorang artinya sudah mampukah dia memahami tata cara pelaksanaannya mulai dari syarat-syaratnya, rukunrukunya, sunnat dan wajibnya haji bahkan sampai kemakna pelaksanaan ibadah haji itu sendiri.

Ada kepercayaan yang diyakini sebagian orang Bugis, naik haji pada dasarnya juga ditentukan oleh toto' (takdir). Seseorang yang pada awalnya sama sekali tidak cukup biaya untuk ke tanah suci namun hanya dengan niat dan keyakinan yang tulus, namun ternyata mampu menjalankan ibadah haji dengan rezeki yang tak terduga kedatangannya. Sehingga ada diantara orang Bugis mengatakan: Toto'pa penre'i tauwe ritana marajae, narekko naratteni wettunna engkanitu pangngolli'na puangnge nasibawai cenning atinna atanna (takdir yang menentukan seseorang melaksanakan ibadah haji, kalau waktunya sudah tiba maka Allah akan mengundang hambanya beserta dengan hati yang tulus dari hambanya). Jadi, petuah leluhur orang Bugis tersebut bermakna bahwa takdir dan niat tuluslah yang menjadi kunci utama keberhasilan seseorang bisa menunaikan ibadah haji. Tidak sedikit orang yang berlimpah materi akan tetapi hatinya tergerak untuk menunaikan ibadah haji.

Namun pada perkembangan selanjutnya, banyak pula terdapat orang yang berada pada tingkat ekonomi menengah kebawah tapi berusaha untuk berangkat haji. Jika dilihat 
dari cara mereka memperoleh dana untuk membayar ongkos naik haji (ONH) dimana berbagai macam cara ditempuh misalnya dengan arisan-arisan terutama arisan haji, meminjam kredit dari Bank atau dengan menjual harta warisan maka pada dasarnya mereka itu belum dikategorikan orang yang mampu secara finansial dan belum termasuk golongan istitha'ah dari pandangan agama. Hal ini juga menandakan bahwa sebenarnya motif utama mereka melaksanakan ibadah haji bukan semata-mata karena ibadah namun karena faktor status sosial.

Dalam berbagai interaksi sosial para haji disamping mendapat perhatian, penghargaan dan penghormatan dari masyarakat, juga ditempat pada strata sosial melebihi komponen masyarakat yang belum berhaji. Tampak kecenderungan masyarakat menggunakan pendekatan agama, seperti ibadah haji untuk meningkatkan, memperbaiki dan mengkokohkan status sosial. Pada sisi lain masyarakat memberikan respon positif terhadap seseorang yang telah berhaji pada status yang lebih tinggi sebagai wujud diterimanya haji menjadi simbol status dan identitas.

Masyarakat Kelurahan Takkalasi sangat menghargai orang-orang yang telah berhaji mengingat ibadah haji merupakan ibadah yang butuh banyak pengorbanan terutama dari segi finansial, hal tersebut akan selalu berlaku selama masyarakat ditempat itu masih menjunjung tinggi nilai-nilai status sosial. Dalam suatu observasi yang dilakukan oleh penulis dalam suatu acara pernikahan yang banyak berperan dalam prosesi acara pernikahan adalah orang-orang yang berstatus haji, mayoritas tempat yang disediakan oleh orang yang menggelar pesta pernikahan ditempati oleh para haji sehingga mereka biasa dipanggil sebagai hajji botting (haji pengantin).

Ada empat indikasi yang menunjukkan kecenderungan orang yang berhaji lebih memilih acara pengantin dibanding acara sosial lainnya dalam menaikkan status sosialnya antara lain: (1) karena acara pernikahan adalah acara yang biasanya dihadiri khalayak dari berbagai lapisan masyarakat, (2) proses acara pernikahan membutuhkan waktu yang lama sehingga peluang dalam menaikkan status sosial para haji terbuka lebar, (3) dalam sejarah masyarakat Bugis, bahwa dalam proses pernikahan adalah tempat melihat silsilah keturunan dan menentukan strata sosialnya dan sampai sekarang masih ada pengaruhnya, (4) perpaduan biaya dalam berhaji dan acara perkawinan pada masyarakat Bugis di Kelurahan Takkalasi menelan biaya yang tidak sedikit, hal inilah merupakan cara mereka menandai dirinya sebagai orang yang memiliki finansial yang cukup. 


\section{b. Faktor Gengsi Sosial}

Secara umum, masyarakat Bugis di Kelurahan Takkalasi sangat menghargai simbol haji, mereka menganggap simbol haji memiliki banyak kelebihan karena mendapatkannya tidak mudah, membutuhkan banyak pengorbanan baik dari segi materi maupun secara fisik. Bagi mereka yang tidak menunaikan ibadah haji dianggap tidak memiliki kedudukan apa-apa di tengah masyarakat sehingga pola pikir ini sedikit banyaknya memengaruhi mental spiritual seseorang dari makna takwa ke gengsi sosial karena mereka melaksanakan haji bukan lagi mengenai persoalan ibadah tetapi mereka lebih cenderung untuk mendapatkan gelar haji agar mendapatkan kedudukan yang terhormat di tengah masyarakat.Menurut paradigma dramaturgi bahwa masing-masing dari mereka tentunya mengutamakan yang namanya penampilan, baik itu hiasan dan pernak-pernik yang dikenakan begitu pula dalam hal berbusana, mereka selalu tampil modis dan berusaha untuk selalu eksis dalam kelasnya yang mengutamakan prestise sosial. Hal ini menunjukkan suatu fenomena perilaku orang berhaji untuk menjadikan dirinya sebagai orang yang terbaik diantara orang-orang yang ada di sekitarnya.

Banyak hal yang turut menentukan pengakuan terhadap kedudukan, tidak sematamata karena ekonomi, jabatan, profesi, berpendidikan, akan tetapi juga dipengaruhi oleh simbol-simbol agama. Haji memiliki nilai yang sangat besar dalam masyarakat Bugis, maka mereka sangat menghormati, menghargai dan menjunjung tinggi haji sebagai simbol penghargaan yang melekat pada dirinya sehingga mereka cenderung memanipulasi simbol-simbol haji, memanipulasi simbol-simbol berarti menggunakan sesuatu yang tidak sesuai dengan fungsinya, kalau hal itu terjadi maka nilai tersebut akan mengalami pergeseran. Oleh karena itu cara hidup masyarakat disertai persaingan mencapai prestise sosial mendorong masyarakat mencari pendekatan untuk mengukuhkan prestisenya, salah satu diantaranya adalah haji. Haji disamping berfungsi sebagai identitas sosial juga berfungsi sebagai media perantara mencapai prestise sosial.

\section{c. Faktor ingin dihargai}

Salah satu faktor yang mendorong seseorang ingin secepatnya menunaikan ibadah haji menurut hasil pengamatan di lapangan, karena mereka ingin lebih dihargai di tengahtengah masyarakat. Seseorang apabila telah menyandang predikat haji bisa lebih dihargai terutama dalam acara-acara sosial kemasyarakatan atau keagamaan terutama acara pernikahan. Penghargaan masyarakat di Kelurahan Takkalasi terhadap orang yang sudah berhaji sangat tinggi, mereka lebih menghargai orang yang sudah berhaji daripada guru 
pendidik. Haji identik dengan penghargaan masyarakat. Orang yang belum berhaji jelas tidak bisa mendapatkan penghargaan yang layak seperti halnya dengan orang yang berstatus haji. Oleh karena itu, untuk mendapatkan penghargaan yang layak di tengah masyarakat di Kelurahan Takkalasi maka salah satunya harus menjadi orang yang mendapatkan gelar haji.

Masyarakat Bugis di Kelurahan Takkalasi sangat menghormati dan menghargai gelar haji yang disandang oleh seseorang apabila seseorang sudah berhaji dan jika tidak dipanggil dengan sapaan haji maka ia akan tersinggung. Dilihat dari pandangan interaksionisme simbolik, bahwa sapaan haji pada masyarakat Bugis di Kelurahan Takkalasi yang berstatus haji merupakan cermin rasa senang terhadap dirinya setelah disapa dengan sebutan haji.Interaksi tersebut adalah motivasi orang yang berhaji dalam mengidentifikasi dirinya sebagai orang yang berhaji (significant others). Sebenarnya tuntutan masyarakat yang belum berhaji (general others) sebagai akibat dari pengaruh interaksi orang yang berhaji.Perilaku tersebut bukan merupakan budaya orang Bugis di Kelurahan Takkalasi, tetapi perilaku itu merupakan perilaku individu yang mempengaruhi sebagian orang, karena tidak semua masyarakat di Kelurahan Takkalasi melakukan hal tersebut. Bagi mereka yang memahami makna haji menganggap bahwa simbol haji hanya pelengkap bukan tujuan, tujuannya adalah dilihat dari perilaku seseorang sehari-hari sesuai dengan makna haji yang sebenarnya. Oleh karena itu, setiap ada yang dianggap bernilai dalam satu masyarakat maka kecenderungan masyarakat untuk menghargai, menghormati bahkan mencintai nilai-nilai itu, dan setiap masyarakat pasti ada sesuatu yang dihargainya, sesuatu itu akan menjadi cikal-bakal yang dapat menumbuhkan adanya sistem pelapisan sosial.

\section{Kesimpulan}

Hasil penelitian ini merupakan gambaran empirik tentang pergeseran makna simbolik haji. Bentuk-bentuk pergeseran makna simbolik haji dapat dilihat pada seseorang yang berhaji melalui upacara mappatoppo dan konstruksi pakaiannya. Upacara mappatoppo adalah ritual yang dilakukan oleh orang-orang yang berhaji untuk mendapatkan gelar haji sebagai simbol penyempurna rukun Islam. Upacara mappatoppo memiliki makna bahwa pada dasarnya manusia sama kedudukannya di depan Allah kemudian terejawantahkan di tengah masyarakat hanya yang membedakan adalah tugas dan tanggung jawab. Hal ini dilakukan oleh orang-orang dulu. Kemudian dalam 
perkembangan selanjutnya, makna simbol haji telah mengalami pergeseran karena gelar haji yang diperoleh dalam ritual mappatoppo dianggap memiliki kekuatan dalam mengangkat derajat seorang haji di tengah masyarakat. Kemudian konstruksi pakaian haji yang diintruksikan pada upacara mappatoppo adalah pakambang, taliling, mispa, dan surubeng. Ada tiga faktor yang menjadi pendorong terjadinya pergeseran makna simbolik haji yaitu pertama; karena status sosial, kedua; karena gengsi sosial, ketiga; karena ingin mendapatkan penghargaan lebih tinggi di tengah masyarakat.

Berdasarkan penelitian yang diperoleh dan telah diuraikan sebelumnya, maka disarankan agar para haji bersikap dan berperilaku sesuai dengan nilai-nilai ajaran Islam dan memaknai gelar haji sebagai media pembinaan proses kesadaran beragama dalam rangka membentuk kepribadian yang agamis. Hendaknya gelar haji dijadikan sebagai media dalam mengintensifkan hubungan kepada Allah dan terejawantahkan ke dalam hubungan kepada masyarakat yang belum berhaji dan tidak dijadikan gelar haji sebagai alat untuk membedakan dan menjaga jarak dengan orang yang belum berhaji. Selanjutnya, saran penelitian adalah agar setiap orang ingin melaksanakan ibadah haji benar-benar memiliki niat yang tulus dan ikhlas semata-mata karena Allah SWT dan bukan hal-hal lain yang hanya bersifat keduniaan seperti ingin mendapatkan status sosial, gengsi sosial dan ingin mendapatkan perhargaan yang lebih tinggi di tengah masyarakat.

\section{Daftar Pustaka}

Arfah, Muhammad \& Amir, M. (1993). Haji Andi Mappannyukki Sultan Ibrahim. Ujung Pandang: Departemen Pendidikan dan Kebudayaan.

Badrun, H. P. D. (1997). Badrun, H.P. Ujung Pandang: Departemen Pendidikan dan Kebudayaan.

Kahmad, D. (2006). Sosiologi Agama. Bandung: Remaja Rosdakarya.

Mattulada. (1995). Latoa Satu Lukisan Analisis Terhadap Antropologi Politik Orang Bugis. Ujung Pandang: Hasanuddin University Press.

Moleong, L. J. (2006). Metode Penelitian Kualitatif. Bandung: Remaja Rosdakarya.

Mukhlis. (1999). Landasan Kultural dalam Pranata Sosial Bugis-Makassar, dalam Mukhlis (ed), Dinamika Bugis-Makassar,. Makassar: Pusat Latihan Penelitian Ilmu-ilmu Sosial dan YIIS.

Mulkhan, A. M. (1998). Perubahan Perilaku Politik dan Polarisasi Umat Islam 19651987 dalam Perspektif Sosiologis. Jakarta: Rajawali Press.

Sensa, Moh. Djarot \& Artyasa, U. S. (2004). Haji Spiritual (Makna Filofofis-Esoteris dalam Pendakian Ruhani. Bandung: Humaniora.

Silalahi, U. (2009). Metode Penelitian Sosial. Bandung: Refika Aditama. 